\title{
KEBIJAKAN JAMINAN FIDUSIA PADA PEMBIAYAAN MURABAHAH DI BANK SYARIAH MANDIRI KANTOR CABANG PEMBANTU MERDEKA BOGOR
}

\section{FIDUCIARY GUARANTEE POLICY ON MURABAHAH FINANCING AT BANK SYARIAH MANDIRI BRANCH MERDEKA BOGOR}

\author{
Irfan Taufik Sholihin'1a; T. Rifqy Thantawi ${ }^{2}$ \\ 1aProgram Studi Perbnkan Syariah Fakultas Ekonomi Islam Univeersitas Djuanda, Jl. Tol \\ Ciawi No. 1, Kotak Pos 35 Bogor 16720, e-mail: irfantaufiksholihin@gmail.com. \\ 2Program Studi Perbankan Syariah Fakultas Ekonomi Islam Universitas Djuanda, Jl. Tol \\ Ciawi No. 1, Kotak Pos 35 Bogor 16720
}

\begin{abstract}
In the practice of providing financing by Bank Syariah, fiduciary guarantee becomes a very calculated object in the trial. Because fiduciary security is processed through a notary and witnessed by legal persons. There is also the posibility of problems related to the implemntation of teh financing agreement with fiduciary guarantee concerning the decrease of the selling price after teh aution is condccted by the Sharia Bank. The research method that will be used by the researcher is case study or case study, with the research specification used is descriptive qualitative. The results of this study can be conclded tht the implemntation of fiduciary guarantee policy in Syariah Mandiri Bank Branch Merdeka Bogor branch that the financing above Rp. 100.000 .000 is required to use fiduciary guarantee, while for under Rp.100.000.000, for example Rp.70.000.000 depemding on the result of meeting, whether approved to get fiduciary guarantee or not.
\end{abstract}

Keywords: Fiduciary, Policy, Mandiri Syaria Bank, Murabahah

\begin{abstract}
ABSTRAK
Praktik pemberian pembiayaan jaminan fidusia di bank syariah menjadi objek yang sangat diperhitungkan dalam persidangan karena prosesnya melalui notaris dan disaksikan oleh orang-orang hukum. Selain itu, tidak menutup kemungkinan munculnya permasalahan-permasalahan yang berkaitan dengan pelaksanaan perjanjian pembiayaan pada jaminan fidusia yang menyangkut penurunan harga jual setelah pelelangan dilakukan oleh pihak bank. Adapun metode penelitian yang digunakan peneliti yaitu case study atau studi kasus, dengan spesifikasi penelitian deskriptif kualitatif. Setelah dilakukan proses penelitian maka kesimpulannya adalah pelaksanaan kebijakan jaminan fidusia di Bank Mandiri Syariah Kantor Cabang Penbantu Merdeka Bogor bahwa pembiayaan di atas Rp. 100.000 .000 diharuskan menggunakan jaminan fidusia, sedangkan untuk dibawah Rp.100.000.000, misalnya Rp.70.000.000 tergantung dari hasil rapat, apakah disetujui untuk mendapatkan jaminan fidusia atau tidak.
\end{abstract}

Kata Kunci: Fidusia, Kebijakan, Bank Syariah Mandiri, Murabahah

Irfan Taufik Solihin. 2018. Kebijakan Jaminan Fidusia Pada Pembiayaan Murabahah Di Bank Syariah Mandiri Kantor Cabang Pembantu Merdeka Bogor. Jurnal Nisbah 4 (2): 132-144. 


\section{PENDAHULUAN}

Pembangunan ekonomi sebagai pembangunan nasional salah satu cara untuk mencapai kesejahteraan pada rakyat yang baik, bijaksana, adil dan makmur. Dalam rencana membangun pemerintahan maupun kemasyarakatan, memerlukan suatu dana yang besar. Sehubungan dengan pembangunan yang meningkat, maka kebutuhan kita pun akan lebih meningkat. Sebagian besar dari dana yang kita perlukan untuk dapat memenuhi kebutuhan-kebutuhan tersebut dengan melalui sistem pinjam meminjam (Purwahid dan Kashadi, 2008).

Keperluan dana untuk menggerakkan mata pencaharian perekonomian yang dirasakan sudah semakin meningkat secara terus-menerus. Di beberapa sisi yang dilihat oleh masyarakat ada yang sudah kelebihan dana akan tetapi masyarakat tersebut tidak memliki kemampuan dalam mengusahakannya begitu juga dengan masyarakat yang memiliki kemampuan berusaha tapi terkendala masalah dana bahkan tidak memiliki dana.

Seperti halnya zaman sekarang yang menjadi kendala masyarakat untuk menjalankan kehidupannya dengan bekerja dan juga berusaha. Hal ini menjadi faktor utama yang dicari oleh masyarakat, contohnya ketika kita akan melakukan usaha tetapi masyarakat tidak mempunyai sama sekali modal pertama sehingga usahanya tidak berjalan. Fenomena seperti ini mendorong masyarakat untuk mendatangi bank dengan tujuan mendapatkan jaminan atau pinjaman yang akan disediakan untuk disalurkan bank melalui fasilitas jaminan guna untuk memuluskan usaha mereka.

Peminjaman uang dalam istilah perbankan Indonesia disebut dengan kredit. Salah satu usaha pokok dari bank yaitu memberikan kucuran dana kepada nasabah atau memberi pembiayaan. Kredit perbankan disalurkan bank kepada masyarakat dengan tujuan untk menyesuaikan kebutuhan masyarakat dan fungsinya masing-masing.

Dalam Undang-Undang (UU) Nomor 10 pada tahun 1998 mengenai Perbankan menyebutkan pengertian bank yaitu:

"Bank merupakan badan usaha yang mempunyai peranan untuk dapat menerima dna menyalurjan daan berupa simpanan serta menyakurkannya keoada maayarakat berupa bentuk-bentuk kredit tertentu atau bentuk lainnya untuk dapat mencapai sebuah tujuan utama."

Dalam praktiknya, fidusia sering ditemukan dalam perdagangan dan perbankan terkait dengan kesepakatan bersama, salah satunya hutang piutang maupun jaminan kredit. Jaminan fidusia diadakan karena masyarakat sangat membutuhkan adanya sebuah jaminan dimana barang yang dapat dijaminkan akan tetap berada pada pemiliknya untuk dapat menjalankan usahanya. Dengan demikian, fidusia yaitu merupakan perjanjian accesoir yang berupa tambahan dari beberapa pokok perjanjian berupa suatu perjanjian mengenai hutang dan piutang yang jaminannya yaitu benda yang bergerak (baik benda berwujud dan tidak).

Adapun yang dimaksud yang terdapat pada Undang-Undang No.4 di Tahun 1996 mengemukakan berupa Hak Tangungan yang berada pada penguasaan pemberi jaminan fidusia, guna memberikan agunan bagi pelunasan hutang, yang berfungsi untuk memberi kedudukan yang telah diutamakan untuk penerima fidusia kepada kreditur.

Lahirnya bank sesuai pada bidangnya berdasarkan syariah pada tahun 2008 yaitu Undang-Undang No.21 tentang Perbankan Syariah yang mencakup bahwa:

a. Berjalannya pembangunan nasional Indonesia yang bertujuan untuk dapat tercapai masyarakat adil dan makmur dalam demokrasi perekonomian, telah dikembangkan sistem perekonomian 
yang sesuai pada nilai-nilai kebersamaan, keadilan, kemanfaatan, dan pemerataan yang sudah sesuai prinsip Islam dengan syariah.

b. Kebutuhan semua masyarakat Indonesia terhadap suatu pelayanan jasa pada perbankan syariah yang semakin terus menerus meningkat.

c. Perbankan syariah dilihat memiliki suatu kekhususan dibandingkan oleh perbankan konvensional.

d. Berdasarkan pertimbangan yang telah disepakati sebagaimana huruf yang dimaksud adalah huruf konsonan a sampai d diperlukan membentuk sebuah Undang-Umdang tentang Perbankan Syarah (Bank Indonesia, 2016).

Bank merupakan jasa layanan atau lembaga keuangan dalam kegiatannya menyalurkan dana bagi masyarakat memberikan fasilitas pembiayaan. Demi sebuah kepastian hukum dan keamanan yang sudah ditentukan, diperlukan adanya sebuah jaminan bagi sistem pembiayaan yang sudah dilakukan oleh bank terkait. Hal ini mendorong masyarakat untuk mendatangi bank dengan tujuan mendapatkan jaminan atau pinjaman yang sudah diberikan guna melancarkan usaha mereka. Dikarenakan banyak masyarakat memerlukan akan kurangnya biaya usaha untuk menjalankan kehidupan. Bank Syariah Mandiri memfasilitasi pembiayaan yang dilaksanakan dengan akad murabahah guna mempermudah transaksi antara sang debitur dan kreditur. Terdapat juga pelaksanaan jaminan fidusia berpotensi terjadinya masalah di tempat yang akan dijadikan objek penelitian.

\section{MATERI DAN METODE}

\section{Bank Syariah}

Perbankan Syariah yaitu segala sesuatu yang terikat oleh bank syariah dan unit-unit kegiatan usaha syariah yang telah mencakup kelembagaan, kegiatankegiatan usaha, serta bagaimana proses pelaksanaannya sesuai jenis usahanya. Bank syariah adalah bank ysng menjalankan suatu jenis usahanya berlandaskan prinsip sesuai dengan syariah Islam dan sesuai jenis bank syariah itu terdiri antara lain; BUS, UUS dan BPRS. (UU Nomor 21 Pada Tahun 2008 menjelaskan tentang Perbankan Syariah).

Di Indonesia, lembaga perbankan syariah didirikan pertama kali pada tahun 1992. Walaupun dalam perkembangannya agak sedikit lamban dibandingkan negara yang mayoritas muslim lainnya, bank syariah di Indomesia akan semakin berkembang. Di dalam periode di tahun 1992 sampai dengan tahun 1998 bahwa hanya akan ada suatu unit lembaga Bank Syariah. Selanjutnya pada tahun 2005 bank syariah telah bertambah lagi menjadi ada 20 unit antara lain yaitu 3 bank syariah serta 17 uniit usaha syariah. Sekarang hingga pada tahun 2016 bank syariah di Indonesia berjumlah 199 unit bank syariah. (Otoritas Jasa Keuangan, 2016)

Bank syariah adalah lembaga yang terbiasa menjalankan suatu kegiatan yang berlandaskan oleh prinsip syariah yamg terdiri dari lembaga Bank Unum serta Bank Pembiayaan Rakyat. Usaha membentuk sistem ini harus didasari oleh nilai-nilai agama Islam baik dalam meminjam dengan adanya bunga serta adanya larangan investasi pada usaha yang sudah dikategorikan haram atau kurang sesuai dari syariah Islam. Oleh karena itu, dilakukannya sistem perbankan konvensional. Persaingan antar usaha bank yang mendorong dan memaju Lembaga untuk membuat inovasi produk pada suatu sistem lambaga di kegiatan usahanya dalam berbagai keunggulan yang bersifat kompetitif. Dalam kondisi Bank konvensional sekarang yang akan menghadapi beberapa persaingan yang baru dengan adanya kehadiran suayu lenbaga keuamgan konvensional ataupun bank non-konvensional. Dikarenakan hal 
ini telah dikenal dengan perkembangan sustu lenbaga keuamgan pada bank dengan sistem menurut syariah Islam.

\section{Fungsi Bank Syariah}

Lembaga keuangan berbasis Syariah ini memiliki 3 fumgsi utama yairu antara lain fungsinya untuk menyimpan seluruh dana masyarakat dalam berbentuk investasi, bertujuan menyalurkan sebagain dana kepada yang membutuhkan yaitu masyarakat, dan untuk memberikan jasa pelayanan ysng samgat bsik dalan bemtuk jssa perekonomian syariah. Ismail (2013) mengemukakan bahwa fungsi bank syariah yaitu:

\section{Menyimpan Dana Masyarakat}

Fungsi bank syari'ah yaitu menyimpan seluruh dana dari surplus unit. Bank syari'ah menghinpun dama dsri berbagai masyarakat yang berbentuk titipan dan dengan menggunakan akad yang sudah disepskati berupa investasi dengan menggunakan perjanjian mudharabah.

Wadiah yaitu suatu akad dimana pihak terkait pertama yaitu masyarakat bersangkutan dengan pihak kedua yaitu bank, pihak pertama memiliki kewajiban untuk berkontribusi dalam menitipkan dana yang tekah disediskan kepada bank, bank berhak untuk menerima dan menyimpan titipan tersebut untuk di memanfaatkan titipan tersebut pihak pertama dalam model transsksi yang sudah diperbolehkan dalam Islam.

2. Menyalurkan Dana Pada Masyarakat

Pada fungsi kedua, bank syari'ah menyimpan dana untuk madyarakat yang membytuhkan agar mereka mendapat kesempatan menerima suntikan dana dari lembaga tersebut dengan syarat dapat memenuhi persyaratan ketentuan yang suddah ditenyukan pihak bank tersebut. Menyinpan dan menyalyrkan daana merupaakan aktivitas yang bagi dan penting untuk bank syari'ah. Oleh sebab itu bank syari'ah memperoleh dana yang disalurkan. Pendapatan yang sudah didapat bank syari'ah dari sistem yamg telsah dittapkan unttuk penyaluran dana ini sesuai juga pada akadnya yang telah ditetapkan.

Bank syariah mennghimpun dan menyalrkan dana untuk yang membutuhkan seperti masyarakat dengan bermacam akad, adapun akad yang sudah ditentukan, antara lain macam-macam akad yang akan ditentukan adalah aksd juaal beli, kemitraan dan kerja sama usaha. Pada akad jual beli, dalam bentuk margin keuntungan pihaak bamk akan mereturn seluruh penyaluran dana yang sudah dikeluarkan. Adapun margin keuntungan merupakan hasil selisih dengan harga tetap yang teelah ditetspkan untk nasaabah dan harga beli untuk bank tersebut. Pendapatan sudah diperoleh menyalurkan sebagian danaa kspada deditur demgan menggunakan salah satu, antara lainnya ialah akad kerja sama yaitu bagi hasil.

\section{Memberikan Pelayanan Jasa}

Fungsi bank syari'ah yaitu memberikan jasa perbankan yang baik untuk nasabahnya. Pelayaman jasa yamg dilakukan bank syari'ah merupakan bentuk pemenuhan kebutuan masyarakat untuk mempermudah dan membantu mereka dalam menjalankan aktifitas sehari-hari. Pelayanan berupa jasa yang akan diberikan debitur merupakan sebuah fungsi dari bamk syarih teersebut dan termasuk yang ketiga. Salah satunya macam-macam jenis produk-produk pelayanan jasa seperti transfer, pemindahbukuan.

Aktivitas lain seperti pelayanan jasa merupakan aktivitas yang selalu diharapkan dan dibutuhkan oleh bamk sysri'ah umtuk daspat mencapai sebuah tujuan guna meningkatkan sebuah pendapatan bank berasal dari fee ataau yamg bissa kita kenal dengan sebutan biaya kepada layaman jasa bsnk iyu semdiri. Ada beberapa bank sekalu berussha umtuk dapat meningkatkan layanan teknologi bagian konunikasi dan infornasi guna dapat memberikan sebuah 
jasa layanan yang selalu memuaskan hati para nasabah. Sakahsatu nilsi baik dari sebuah pelayanan yaitu dapat memuaskan nasabah, ramah dan sopan, serta jasa pelayanan cepat sesuai waktu dan akurat. Bank berlomba-loma untuk dapat berinovasi lebih baik umtuk menggapai tujuam guna meningkatkan seperti kualitas produk, jasa layanan agar semakin baik. dengan pelaysnan yang samgat baik dan dapat memuaskan nasabah, maka dari itu bank syari'ah sendiri akan mendapat hadiah berupa fee yang disebut fee based income.

\section{Kebijakan}

Kebijakan yaitu suatu perkataan atau tulisan berupa perintah sebagai pemodan atau petunjuk yamg memberi batas kesempatan untuk umum jika ingin bergerak. Baik secara etimologis, kebijakan yaitu terjemahan dari kata policy. Yang dimaksud dari kebijakan yaitu sebagai rangkaian konsep yang menjadi pelaku dalam melaksanakan sesuatu pekerjaan. Kebijakan dapat berbentuk sebush kepuyusan yang sudah dipikirkan secara logika dan matang serta diperhatikan kehati-hatiannya oleh seseorang pengambil keputusan dengan cara berulang serta terkait atas aturan dari keputusan yang telah ditentukan.

\section{Pengertian Fidusia}

Fidusia yaitu pengalihan hak suatu kepemilikan dari sebuah benda yang didasari atas kepercayaan sesuaai dengan ketemtuan sebagaimana telah ditetapkan bahwa obyek tersebut dialihkan akan tetapi tetap dalan pengussaan suatu pemilik benda tersebut.

Dari pemaparan dapat kita diketahui unsur dari fidusia yaitu:
a. Pengalihan suatu hak dalam kepemilikan benda atau barang;
b. Dilakukan dasar suatu kepercayaan;
c. Kebendaan penguasaan dimiliki oleh pemilik benda.

Dari penjelasan di atas dapat dikatakan dalam fidusia terjadi pemindahtanganan dalam kepemilikan dari sesuatu benda yang dilakukan secara kepercayaan dengan persyaratan yang telah ditentuksn bahwa benda yang meniliki hak dalsm kepemilikan objek tersebut diserahkan dan diterima oleh penerima fidusia berada dalam kuasa pemilik hak benda tersebut. Dalam hal ini yang harus diserahkan dan di pindahkan dari pemiliknya hanya yang memiliki hak kepemilikan dari suatu bemda dapat dijadikan sebuah jaminan, sehingga beralih kepada kreditor (penerima fidusia). Semantara itu hak kepemilikan secara ekonomis suatu benda akan berada di tangan penguasa pemiliknya.

\section{Pengertian Jaminan Fidusia}

Jaminan fidusia yaitu hak suatu jaminan benda yang dapat bergerak baik berwujud atau tidak, serta sebuah benda yang tidak bergerak antara lain bangunan yang tak dibebani oleh hak tanggungan. Hal ini berdasarkan Undang-Undang Nomor 4 pada tahun 1996 mengenai Hak Tanggungan yang akan tetap akan berada dalam sebuah penguasaan pemberi jaminan fidusia sebagai agunan bagi sitem pelunasan hutang dan piutang tertentu, yang menjadi kedudukan akan lebih diutamakan kepada hak penerima jaminan fidusia kepada kreditor lainnya". Berdasarkan perumusan dalam Pasal satu pada angka 2 Undang-Undang Jaminan Fidusia, unsur-unsur dari jaminan fidusia yaitu:

a. Sebagai lenbaga hak jaminan kebemdaan dan hak yang diutamakan.

b. Kebendaan bergerak sebagai objeknya.

c. Kebendaan yang tidak bergerak.

d. Kebendaan menjadi sebuah objek jaminan fidusia dimaksudkan sebagai agunan.

e. Memberikan kedudukan yang akan diutamakan untuk penerima hak fidusia terhadap kreditor lainnya.

Jadi dapat disimpulkan bahwa fidusia merupakan sebuah proses dari pengalihan hak kepemilikan, dan jaminan fidusia merupakan jaminan yang telah diberikan berbentuk fidusia. 
Di dalam perbankan terdapat lima (5) faktor ysng diterapkan lembaga untuk melakukan penilaian terhadap debitur, yang terkenal dengan sebutan "The Five of Credit Analysis" atau disebut dengan 5C (Character, Capital, Capacity, Collateral and condition) (Djumhana, 1995). Yang dimaksud prinsip 5 (lima) C yaitu:

\section{Character (Watak)}

Yaitu suatu sifat yang ada didalam hati seseorang. Watak merupakan suatu penilaian penting untuk dipertimbangkan agar tidak terjadi gagal bayar setelah pembiayaan diberikan.

\section{Capital (Modal)}

Seseorang atau perusahaan ingin merintis dari awal menjalankan suatu usaha atau bisnis akan sangat diperlukan modal umtuk menjalsnkan kegiatan bisnisnya.

\section{Capacity (Kemampuan)}

Adalah kemampuan kreditur untuk menuntaskan kewajibannya tersebut. Dari pihak bank itu sendiri harus melihat aruskas dan laporan keuangannya agar terlihat seberapa besar kemampuannya dalam menyelesaikan pembiayaan.

4. Collateral (Jaminan)

Yaitu suatu jaminan yang mana sangat berguna untuk memberi hak dan kekuasaannya kepsda pihak bamk untuk menyelesaikan pelunasan, bilamana debitur tidak bisa melunasi hutangnya.

\section{Condition (Kondisi)}

Adalah pertimbangan terhadap jenis pembiayaan yang diajukan nasabah kepada Lembaga, usaha yang diajukan harus sesuai dengan keadaan ekonomi negara pada saat itu, penialai ini berguna untuk memprediksi dan meminimalisir risiko gagal bayar. (Sutarno, 2009).

\section{Pembiayaan Murabahah pada Bank Syari'ah}

Istilah di dalam perbamkan syariah, pinjam meminjam tidak dapat untuk digunakan karena sistem pinjam meminjam ini termasuk metode finansial di dalan Islam selain jual beli dan pembagian hasil. Selain itu, pinjammeminjam dalam islam seharusnya yaitu akad sosial yang niatnya untuk membantu seseorang, bukan seperti akad komersial, yang artimya jika ssseorang meminjamkan sesuatu, maka dari pinjaman tersebut tidak diperbolehkan untuk mencoba memberikan tambahan pada pokok pinjamannya dikarenakan setisp pinjsman yang menghasilan manfaat adalah riba, sedangkan riba di dalam Islam termasuk haram hukumnya. Karena itu, di dalam perbankan syari'ah pinjaman itu sendiri tidak disebut dengan kata kredit melainkan disebut pembiayaan. Pada pasal 1 ayat 12 Undang-Undang Nomor 21 Pada Tahun 2008 mengenai Perbankan Syariah adalah:

"Pembiayaan berdasarkan syari'ah merupakan jasa penyediaan beberapa dana serta tagihan yang disamakan dengan itu tentunyan yang telah sesuai dengan kesepakatan antara bank terkait dengan pihak lainnya, sehingga mewajibkan keoada pihak yang telah dibiayai untuk dapat mengembalikan uang dalan kisaran waktu yamg telah ditentuksn berupa sistem bagi hasil yang telah disetujui diawal".

\section{Syarat dan Rukun Pembiayaan Murabahah \\ Dalam pelaksanaan pembiayaan murabahah dituntut diharuskan untuk memenuhi persyaratan dan rukun-rukun yang disepakati, di antaranya adalah:}

a. Syarat
1) Terdapat barang di tempat ataupun tidak, adanya kesanggupan untuk dapat mengadakan barang itu,

2) Barang tersebut mempunyai hak dimiliki oleh seseorang,

3) Terdapat sifat terwujud dari benda tersebut,

4) Sifat arang tersebut tidak bersangkutan dari kategori haram 
5) Teknis penjualannya harga jual ditambah dengan keuntungan,

6) Tidak boleh berubahnya harga jual (QS. An-Nisa: 29),

7) Sistem pembayaran pada kurun waktu ysng disepakati bersama.

b. Rukun

\section{1) Sigat ijab qabul}

2) Penjual (bai') dan pembeli (musytari)

3) Obyek sistem jual beli barang dan harga (tsaman)

\section{Jenis Penelitian}

Jenis penelitian yang telah dilakukan adalah penrlitian deskriptif kualitatif. (Bogdan dan Taylor, 1992: 21-22) mengemukakan penelitian kualitatif yaitu prosedur yang akan menghasilkan datadata deskriptif antara lain berupa ucapan, perilaku dan tulisan dari obyek yang telah diamati. Pendekatan dari kualitatif itu sendiri diharapkan akan mampu meunjukkan suatu uraian yang real dan mendetail tentang tulisan, ucapan, serta perilaku yang diamsti dari individu, masyarakat, kelompok dan organisasi tertentu didalam konteks tertemtu yang sudah dikaji dari penglihatan sudut pandamg yang benar dan utuh, komprehensif, serta holistik.

\section{Metode Penelitian}

Penelitian kualitatif yang digunakan dalan karya ilmiah ini menggunakan metode study kasus (case study). Case study metode yang mengalami kejadian tertentu secara lebih real dan mendalam dengan melibatkan seluruh pengumpulan sumber informasi.

Bimo Walgito (2010: 92) mengemukakan bahwa, studi kasus diartikan salah bentuk satu metode untuk dapat menyelidiki suatu peristiwa ysng terjadi pada seseorang (riwayat hidup). Pada studi kasus ini diperlukanya banyak sekali sumber-sumber informasi. Hal ini agar mendapat bahan-bahan yang agak mendalam dan lebih luas. Metode ini salah satu integrasi dari suatu data yang didapatkan dengan metode lainnya.
Metode studi kasus yang sudah dipilih karena dianggap sesuai dengan penelitian peneliti, yang akan dipakai untuk melihat suatu fenomena yang terjadi pada proses berlangsungnya proses peminjaman jaminan dengan pembiayaan perjanjian murabahah pada bank syariah.

\section{Teknik Pengumpulan Data}

Teknik ini merupakan langkah mudah dalam sebuah penulisan penelitian, karena tujuan utamanya penelitian ini yaitu ingin mendapatkannya data yang sudah memenuhi standar. Tanpa dapat mengetahui teknik-teknik pengumpulan data lainnya, maka peneliti sendiri tidak berhak memperoleh data yang telah memenuhi syarat dan standar data yang telah ditetapkan (Sugiyono, 2014: 224). Adapun teknik yang akan digunakan pada penelitian ini, antara lain:

\section{Wawancara}

Menurut Esterberg dalam Sugiyono (2014: 231) mendefinisikan bahwa wawancara (interview) adalah pertemuan kedua belah pihak untuk saling bertukar informasi yang dilakukan dengan menggunakan cara penilaian tanya jawab, sehingga menghasilkan makna yang terperinci dalam topik tertentu. Adapun metode dari teknik wawancara yang sudah digunakan oleh peneliti yaitu wawancara semi terstruktur, dimana peneliti bertujuan untuk mendapatkan informasi-informasi yang lebih jauh dan detail tentang objek yang ingin diteliti, sehingga peneliti mendapat gambaran permasalahan lebih akurat dan lengkap. Wawancara ini dilakukan kepada Kepala Mikro Bank Syariah Mandiri Kantor Cabang Pembantu Merdeka Bogor.

2. Observasi

Observasi yaitu metode pengumpulan berbagai macam data melalui pengamatan atas gejala yang sudah dilihat sebelum dan sesudah penelitian, fenomena dan fakta yang terkait dengan permasalahan penelitian (Musfiqon, 2012: 120). Observasi yang tetapkan oleh peneliti adalah metode 
observasi non partisipan. Pada observasi ini, peneliti tidak terlibat langsung dalam kehidupan orang-orang yang akan diobservasi, melainkan hanya mengamati proses peminjaman jaminan debitur kepada kreditur.

\section{Dokumentasi}

Dokumentasi bertujuan sebagai suatu cacatan pada sebuah peristiwa yang telah terjadi bahkan berlalu. Dokumentasi juga dapat berbentuk sebuah gambar, lukisan,tulisan atau sebuah karya seseorang atau benda. Dalam penelitian tersebut teknik dokumentasi diperoleh dari foto-foto pribadi dan tulisan-tulisan yang berkaitan dan rekaman proses peminjaman jaminan debitur kepada kreditur.

\section{Sumber Data}

Sumber data yang akan digunakan di dalam penelitian ini terdiri atas data premier dan sekunder. Data-data tersebut deperoleh melalui:

\section{Data premier}

Data primer yaitu data pokok yang menjadi sumber dalam penelitian, dilakukan melalui wawancara, studi kasus, observasi, dokumentasi dan lainya (Arikunto, 2010: 145). Data premier dalam penelitian ini deperoleh dari hasil wawancara, studi kasus, observasi, dokumentasi langsung yang dilaksanakan di Kantor Cabang Bank Syariah Mandiri Merdeka Bogor yang dituju terdiri dari pihak-pihak yang berhubungan langsung dan memahami terhadap pelaksanaan dan permasalahan pada pembiayaan murabahah yang dikaitkan dengan jaminan fidusia.

2. Data sekunder

Data sekunder yaitu merupakan data yang bertujuan untuk digunakan sebagai data pendukung dan penunjang dalam penelitian (Arikunto. 2010: 157). Data sekunder dapat diperoleh dari data-data internal Bank Syariah Mandiri Kantor Cabang Pembantu Merdeka Kota Bogor seperti buku, internet, dan bahan pustaka lainnya yang berkaitan dengan penelitian ini.

\section{Validitas, Reliabilitas dan Objektivitas}

Validitas data yang ada pada suatu penelitian kualitatif terdiri dari bermacam-macam. Menurut Sugiyono (2013: 361) validitas memiliki dua macam penelitian, antara lain validitas eksternal dan internal. Validitas internal berhubungan dengan derajat akurasi sebuah desain penelitian dengan yang menghasilkan target capaian. Sedangkan, validitas eksternal berhubungan dengan derajat akurasi dari hasil penelitian diterapkan pada semua populasi untuk mengambil sampel. Dalam penelitian kualitatif, validitas internal disebut sebagai Kredibilitas (credibility) dan validitas eksternal disebut sebagai Keteralihan (transferability).

Kredibilitas/validitas internal yang telah diterapkan dalam sebuah penelitian adalah dengan menggunakan peningkatan ketekunan, triangulasi sumber data, bahan referensi dan mengadakan member check. Sedangkan, Keteralihan/validitas eksternal dalam penelitian ini yaitu berkenaan dengan pertanyaan penelitian sehingga hasil dari penelitian sendiri dapat diterapkan pada situasi yang lainnya (Sugiyono, 2013: 365).

Reliabilitas sangat sederajat dengan konsistensi temuan atau stabilitas data. Dalam penelitian kualitatif, reliabilitas disebut sebagai dependability. Suatu data dikatakan reliabel apabila seseorang lain dapat mengulanginya atau mereplikasi suatu proses penelitian tersebut dan dilakukan dengan melakukan metode audit terhadap seluruh proses penelitian yang sedang berjalan (Sugiyono, 2013: 373).

Objektivitas berhubungan erat dengan derajat kesepakatan interpersonal seseorang agreement setiap kalangan orang banyak terhadap suatu benda atau barang. Dalam penelitian kualitatif, objektivitas disebut sebagai uji confirmability. Suatu penelitian dinyatakan 
objektif apabila hasil dari sebuah penelitian yang dijalankan telah disepakati banyak orang. uji confirmability mendekati dengan pengujian dependability sehingga pengujiannya juga dapat dilakukan secara bersama-sama (Sugiyono, 2013: 374).

\section{Teknik Analisis Data}

Teknik Analisis data pada penelitian ini yaitu teknik penelitian kualitatif. Kemudian dicoba untuk dirangkaian data pun terkumpul, selanjutnya dilakukanlah analisis data dengan langkah dan serta teknis pengolahan antara lain: (1) Melakukan penyusunan klasifikasi data dan pemilahan; (2) Melakukan pemberian kode data dan penyunting data yang bertujuan untuk membangun kinerja sebuah penganalisis data; (3) Melakukan verifikasi konfirmasi data; dan (4) Menganalisis data yang sudah sesuai dari hasil penelitian.

Pengolahan data dapat dilaksanakan beberapa tahapan. Pada tahap yang pertama pendahuluan penelitian dimulai dari pengolahan data sampai tersusunnya usulan penelitian. Tahap kedua, dilakukannya pengolahan data dengan cara mengola hasil dari metode wawancara serta pengumpulan sumber informasi yang sudah dihasilkan dari lokasi penelitian. Tahap ketiga, data hasil wawancara dilakukan pemeriksaan keabsahan atau keasliannya dengan beberapa nara sumber sebagai informan penelitian serta dapat membandingkan data tersebut dengan berbagai informasi yang terkait. Pada tahap ini, kelayakan data yang baik dan optimal sangat diperlukan untuk proses ini, lengkap serta dapat mempresentasikan semua masalah yang dijadikan suatu obyek penelitian. Tahap akhir pada kegiatan analisis data dalam menjawab semua pertanyaan pada penelitian yang sudah dilakukan dengan melakukan pendekatan metode multimetode yang diambil oleh peneliti untuk melakukan analisis dan mengumpulkan data atau disebut Triangulasi hasil dari penelitian.

\section{HASIL DAN PEMBAHASAN}

\section{Sejarah Bank Syariah}

Didirikan pada tahun 1999, merupakan keberkahan sekaligus hikmah pasca krisisnya ekonomi yang dialami pada tahun 1997 sampai dengan 1998. Sebagaimana telah diketahui, bahwa krisis ekonomi dan moneter meranjak sejak bulan Juli pada tahun 1997 yang disusul dengan krisis multidimensi temasuk juga di panggung politik nasional ,sudah biasa menimbulkan dampak yang beragam negatif yang sangat kuat hal ini berdampak tehadap seluruh sendi-sendi kehidupan masyarakat, terkecuali pada dunia usaha.

Dalam kondisi inilah, industri dalam perbankan nasional yang berada di dominasi oleh bank konvensional mengalami beban krisis yang sangat mempengaruhi luar biasa. Pemerintah akhirnya mengambil cara tindakan yang sedikit extrim dengan merestrukturisasi dan merekapitalisasi sebagian-sebagian bank yang berada di Negara Indonesia, salah satunya adalah unit bank konvensional yaitu PT. Bank Susila Bakti yang mempunyai hak milik yaitu Yayasan Kesejahteraan Pegawai PT. Bank Dagang Negara. Mahkota Prestasi berdampak yang cukup besar dan krisis. BSB berusaha keluar dari situasi yersebut dengan meakukan upaya merger dengan beberapa bank lain serta mengundang investor asing.

Pada saat bersamaan pemerintah melakukan merger (penggabungan) terhadap 4 bank yang berada di Negara Indonesia seperti Bank Bumi Daya (BBD), Bank Dagang, Bank Bapindo, dan Bank Exim berubah menjadi PT Bank Mandiri hal ini terjadi tepat tanggal 31 juli pada tahun 1999. Adapun hasil kesepakatan dan kebijakan di dalam penggabungan penempatan pada PT Bank Mandiri. 
Kemudian memiliki hak untuk memiliki Mayoritas baru BSB.

Adapun tindakan yang berlanjut keputusan dari merger (penggabungan), Bank Mandiri telah berupaya dalam konsolidasi untuk membentuk sebuah Tim, yaitu Tim Pengembangan Perbankan Syariah. Salah satu tujuan pembentukan tim ini adalah untuk mengembangkan jasa pelayanan perbankan syariah di dalam perusahaan Bank Syariah Mandiri, sebagaimana bentuk respon yang baik atas diberlakukannya Undang-Undang No. 10 pada tahun 1998 adanya perubahan atas Undang-Undang No. 7 tahun 1992 mengenai perbankan, pada kesempatan ini memberikan peluang yang sangat baik khususnya bank umum untuk melayani transaksi berbasis syariah (dual banking system).

\section{Visi dan Misi Bank Syariah Mandiri}

a. Visi

"Bank Syariah yang terdepan dan modern"

1) Bank Syariah Terdepan

Menjadikan bank Syariah yang unggul, berbasis syariah di antara unit perbankan syariah di seluruh Negara Indonesia pada Consumer, Micro, SME, Commercial, dan Corporate.

2) Bank Syariah Modern

Menjadi bank berbasis syariah dengan jasa teknologi dan layanan mutakhir bernilai baik sehingga dapat melampaui harapan yang besar bagi nasabah.

b. Misi Bank Syariah Mandiri

1) Mewujudkan keuntungan dan pertumbuhan yang sangat baik bagi industri yang berkesinambungan.

2) Meningkatnya jasa layanan berbasis teknoligi yang sangat baik sesuai harapan nasabah dan kualitas produk.

3) Mengutamakan penghimpunan dana yang dibawah harga dan menyalirkan pembiayaan pada sistem segmen ritel.

4) Mengembangkan suatu usaha atas nilai-nilai syariah universal.
5) Mengembangkan sistem manajemen keunggulan maysarakat dan lingkungan pekerjaan yang sangat baik dan sehat.

6) Meningkatkan rasa yang tinggi terhadap kepedulian masyarakat dan lingkungan.

\section{Tugas Pokok Bank Syariah Mandiri}

Adapun tugas pokok yang harus dilakukan :

a. Untuk menghimpun atau menyalurkan dana dari masyarakat

b. Sebagai penyalur dana kepada masyarakat

c. Memberikan jasa pelayanan bank yang baik dan sehat

Profil Bank Syariah Mandiri Kantor Cabang Pembantu Merdeka Bogor

Berada di Jl. Merdeka No. 63 Bogor. Tempatnya sangat strategis yaitu di depan mall Pusat Grosir Bogor (PGB), dekat dengan Pasar Anyar Bogor, dan salah satu kantor yang terdekat dan mudah di jangkau di Bogor Barat.

Alamat : Jl Merdeka No. 63 Bogor

Barat.

$\begin{array}{ll}\text { No.Telp } & : \quad \text { (0251) 8386570, } \\ \text { 8386571 } & \\ \text { Website } & \text { : } \text { www.syariahmandiri.co.id }\end{array}$

Tabel 1.

Struktur Organisasi

\begin{tabular}{|c|c|c|}
\hline NO & Nama & Jabatan \\
\hline 1. & Rafika & Branch Manager \\
\hline 2. & $\begin{array}{l}\text { Rolan } \\
\text { Gistayuda }\end{array}$ & $\begin{array}{l}\text { Branch } \\
\text { Operation \& } \\
\text { Service Manager }\end{array}$ \\
\hline 3. & Erwan M. Rizal & Pawning Officer \\
\hline 4. & Tri Nurisa & Pawning Staff \\
\hline 4. & Didi Iskandar & $\begin{array}{l}\text { Micro Banking } \\
\text { Manager }\end{array}$ \\
\hline 5. & $\begin{array}{l}\text { Ahmad } \\
\text { Wildanil }\end{array}$ & $\begin{array}{l}\text { Micro Financing } \\
\text { Sales }\end{array}$ \\
\hline 6. & $\begin{array}{l}\text { Erlangga } \\
\text { Saputra }\end{array}$ & $\begin{array}{l}\text { Micro Financing } \\
\text { Sales }\end{array}$ \\
\hline 7. & $\begin{array}{l}\text { Sahrul } \\
\text { Romadhan }\end{array}$ & Mitra Mikro \\
\hline 8. & Ahmad Fauqi & $\begin{array}{l}\text { Consumer } \\
\text { Banking } \\
\text { Relationship }\end{array}$ \\
\hline
\end{tabular}




\begin{tabular}{|c|l|l|}
\hline 9. & Ria Andini & $\begin{array}{l}\text { Manager } \\
\text { Banking Staff }\end{array}$ \\
\hline 10. & Ressa Fahregy & $\begin{array}{l}\text { General Support } \\
\text { Staff }\end{array}$ \\
\hline 11. & Maya Nurmalita & Teller \\
\hline 12. & $\begin{array}{l}\text { Puji } \\
\text { Wahyuningtyas }\end{array}$ & Teller \\
\hline 13. & $\begin{array}{l}\text { Farhan } \\
\text { Nugraha }\end{array}$ & $\begin{array}{l}\text { Costumer } \\
\text { Service }\end{array}$ \\
\hline 14. & Galih Riyasti & $\begin{array}{l}\text { Costumer } \\
\text { Service }\end{array}$ \\
\hline 15. & Wahyu & Security \\
\hline 16. & Andrea & Security \\
\hline 17. & Budi & Security \\
\hline 18. & Agung & Security \\
\hline 19. & Solehudin & Driver \\
\hline 20. & Dadan & Office Boy \\
\hline 21. & Dani & Office Boy \\
\hline
\end{tabular}

Sumber: Bank Syariah Mandiri Kantor Cabang Pembantu Merdeka Bogor 2017

Penerapan Bank Syariah Mandiri di dalam Pengikatan Fidusia

Fidusia dapat diartikan suatu pengalihan suatu hak kepemilikan benda atas sebuah dasar kepercayaan berdasarkan ketentuan dalam kepemilikan yang sudah dialihkan dan berada pada hak pemilik benda, contohnya seperti mobil. Manfaat fidusia bagi bank yaitu untuk memperkuat pihak bank secara hukum dalam melaksanakan penarikan atau pelelangan jaminan tersebut.

Perjanjian pembiayaan yang diikat dengan perjanjian fidusia merupakn perjanjian yang berdasarkan azas kepercayaan. Azas kepercayaan dalam suatu hal ini yaitu pihak yang boleh meminjamkan kemudian debitur tersebut memberikan jaminan untuk hutangnya. Jaminan yang terkait tetap berada di debitur, tetapi bukti kepemilikannya disimpan oleh bank untuk mengambil alih jaminan tersebut untuk pelunasan hutang.

Dalam penerapan pemberian pembiayaan jaminan fidusia sama dengan penerapan pada pembiayaan lainnya, namun khusus untuk jaminan fidusia setelah setelah melalu tahapan prosedur, fidusia agar dibuatkan Akta Fidusia di notaris dan kemudian harus segera untuk di daftarkan yang memiliki tujuan yaitu memberikan kepastian pada hukum seluruh pihak. Pada pasal 2 pada Nomor 130/PMK.010/2012 mengenai prosedur pendaftaran jaminan fidusia menyebutkan bahwa sebuah perusahaan mewajibkan pembiayaan untuk dapat mendaftarkan jaminan fidusiatersebut pada pihak bank terhitung pada tanggal proses perjanjian dengan kurun waktu yang sudah ditentukan. Adapun tahapan prosedur jaminan fidusia dengan metode pemberian kredit, yaitu:

a. Tahap Permohonan Pembiayaan

Dalam tahap permohonan pembiayaan ini adalah mengisi form permohonan pembiayaan. Isi dari form pembiayaan tersebut adalah:

1) Identitas Pemohon:
a) Nama lengkap
b) Tempat Tanggal Lahir
c) Jenis jelamin
d) Kartu Tanda Penduduk
e) Pekerjaan
f) Alamat sesuai KTP
g) Nomor telpon
h) Status gelar
i) Debitur bank lain
j) Jumlah pinjaman

\section{Kebijakan Jaminan Fidusia}

Fidusia pada Bank Syariah Mandiri Kantor Cabang Pembantu Merdeka Bogor, dengan limit atau plafon pembiayaan diatas Rp. $\quad 100.000 .000$ wajib menggunakan jaminan fidusia baik dibuatkan akta maupun didaftarkan. Apabila dibawah Rp. 100.000.000 pembiayaannya, tergantung dari hasil komite. Misalnya dana pembiayaan yang diajukan sebelumnya oleh debitur Rp. 70.000.000 pembiayaan, tetapi di komite dimintakan untuk didaftarkan dan dibuatkan akta fidusia, maka dilakukannya pengikatan. Untuk plafon pembiayaan di bawah 50 juta rupiah itu pengikatannya adalah surat kuasa jual bawah tangan, 
yaitu pihak bank dan pihak nasabah. (Didi, Micro Banking Manager, 2017)

Adapun pengertian akta bawah tangan yaitu akta yang dipersiapkan oleh pihak-pihak pribadi secara pribadi, dan bukan melalui notaris. Keuntungan dari akta bawah tangan yaitu:

a. Kebebasan dalam bentuk

b. Pembuatannya tidak dihadapan pejabat hukum

c. Kekuatan dalam pembuktian selama ini tidak di bantah oleh pembuatnya.

d. Dalam hal pembuktian, maka hal yang harus diperhatikan adalah saksi dan bukti lainnya. Oleh karena itu, alangkah baiknya harus dimasukkan data dua orang terkait untuk memperkuat sebuah bukti tersebut.

Adapun resiko akta di bawah tangan yaitu tidak mempunyai pembuktian kepada pihak ketiga yang akan memperkuat ketika di persidangan, apabila akta memiliki suatu nilai kelemahan yang tampak yaitu seperti orang yang menandatangani perjanjian akta tersebut kemungkinan besar dapat merekayasa keaslian dari tanda tangan tersebut.

\section{Proses Pengikatan, dan pelelangan Fidusia untuk Nasabah yang Melanggar Ketentuan \\ Proses Pengikatan}

Proses pengikatan fidusia sebelum dilaksanakannya akad pembiayaan, kepada notaris pihak bank membuat order untuk pengikatan fidusia. Saat penandatangan pembiayan, notaris wajib turut hadir pada pengakadan tersebut, hal ini dikarenakan notaris sebagai saksi dari pengakadan tersebut. Setelah itu ada beberapa berkas akta pengikatan jaminan fidusia yang harus melakukan pentandatanganan oleh pihak bank dan juga nasabah. Selanjutnya fidusia tersebut diselesaikan oleh notaris untuk pendaftaran dan dibuatkan sertifikat fidusia.

Dalam proses pengikatan fidusia, ada 2 tata cara pelaksanaan perjanjian.:
1) Akta dibawah tangan, menjelaskan bahwa akta yang pembuatannya cukup ditandatanganin oleh pembuatnya saja dan dimana saja pembuatannya tidak dapat dihadapan dengan pihak pembuat akta sah sesuai UndangUndang.

2) Akta autentik yaitu akta dimana bentuknya dibuat oleh undang-undang yang dibuat dan dapat berhadapan secara langsung dengan notaris dan pegawai umum yang mempunyai kuasa.

\section{KESIMPULAN DAN IMPLIKASI}

\section{Kesimpulan}

Bank Syariah terbesar di Negara Indonesia yang menyediakan jaminan fidusia. Berdasarkan uraiandi atas, dengan ini penulis dapat menyimpulkan:

1. Dalam melaksanakan jaminan fidusia, pelaksanaannya telah cukup baik, pihak bank sendiri harus berhati-hati dalam memberikan sebuah pembiayaan sebagaimana yang telah diatur pada Undang-Undang tentang perbankan.

2. Dalam kebijakan fidusia itu sendiri, ada beberapa pembiayaan yang sudah dilakukan dan diberikan langsung, bahwa jaminan fidusia yaitu pembiayaan konsumer untuk pembiayaan mencapai 100 juta ke atas, pembiayaan mikro untuk pembiayaan di bawah 100 juta, termasuk dari pembiayaan gadai emas.

3. Kreditur (penerima fidusia) dan debitur (pemberi fidusia) masing - masing memiliki kewajiban yang samadan harus dipenuhi dan khususnya kepada debitur apabila debitur wanprestasi. kreditur dapat melaksanakan pelelangan melainkan penjualan di bawah tangan, sedangkan apabila terjadi resiko barang rusak atau hilang dengan gantinya yaitu barang jaminan yang sama nilainya dengan barang jaminan sebelumnya.

4. Manfaat fidusia untuk bank sendiri yaitu untuk memperkuat pihak bank 
secara hukum dalam melaksanakan penarikan atau pelelangan jaminan tersebut

\section{Saran}

1. Dalam pemberian jaminan fidusia sebaiknya pembiayaan diberikan jangka waktu pendek atau menengah agar barang tidak terjadi penurunan secara signifikan dan dapat mengurangi wanprestasi.

2. Sebaiknya dalam menentukan nilai pinjaman bank harus sangat teliti sehingga nilai pinjaman barang saat dijual tidak mengalami penurunan secara mencolok.

\section{DAFTAR PUSTAKA}

Adiwarman A. Karim, Bank Islam Analisis Fiqih dan Keuangan, 2004, PT. Raja Grafindo Persada. Jakarta

Arikunto Suharsimi. Metode Penelitian, 2010, Tineka Cipta.Jakarta.

Gunawan Widjaja dan Ahmad Yani, Jaminan Fidusia, (Jakarta: PT. Raja Grafindo Persada, 2000)

Ismail. Perbankan Syari'ah, 2013, Kencana Prenada Medua Group. Jakarta.

Kahsadi.Hukum Jaminan, Fakultas Hukum Diponogoro, 2000, hal. 59. Diponogor.

Kasmir, Bank dan Lembaga Keuangan Lainnya, (Jakarta: Raja Grafindo Persada, 2008), h. 72
Munir Fuady. Jaminan Fidusia, PT. Citra Aditya Bakti Bandung. 2003.

Munir Fuady. Hukum Perbankan Modern. Citra Aditya Bakti, Bandung, 2003. Hal: 169

Musfiqon, Dr. H.M., M.Pd. Metodologi Penelitian Pendidikan, 2012, Pustakarya. Jakarta.

Oktorio Hery Kusworo, PERJANJIAN KREDIT DENGAN JAMINAN FIDUSIA ATAS KENDARAAN BERMOTOR DI PT BPR ARTHA MUTIARA KAB. SEMARANG, 2012

Purwahid Patrik dan Kashadi, Hukum Jaminan, (Semarang: Universitas Diponegoro Press, 2008)

Raharjo, Susilo dan Gudnanto.Pemahaman Non Individu Teknik Non Tes, Nora Media Eaterprise, 2011. Kudus.

Roestamy Martin, Dr.H,SH,Mh. Hukum Jaminan Fidusia, 2009, Unida Press. Bogor.

Sugiyono, Prof, Dr, Metode Penelitian Kuantitatif dan Kualitatif, 2016, Alfabeta. Bandung.

Syaf'i Antonio, Muhammad. Bank Syari'ah, 2001, Gema Insani Press. Jakarta.

Walgito Bimo. Bimbingan Dan Konseling Studi Dan Karir, 2010, Andi. Yogyakarta. 